Pace University

DigitalCommons@Pace

$1-1-2007$

\title{
Bred Meat-The Cultural Foundation of the Factory Farm
}

David N. Cassuto

Elisabeth Haub School of Law at Pace University

Follow this and additional works at: https://digitalcommons.pace.edu/lawfaculty

Part of the Animal Law Commons

\section{Recommended Citation}

David N. Cassuto, Bred Meat--The Cultural Foundation of the Factory Farm, 70 Law \& Contemp. Probs. 59 (2007), http://digitalcommons.pace.edu/lawfaculty/397/.

This Article is brought to you for free and open access by the School of Law at DigitalCommons@Pace. It has been accepted for inclusion in Pace Law Faculty Publications by an authorized administrator of DigitalCommons@Pace. For more information, please contact dheller2@law.pace.edu. 


\title{
BRED MEAT: THE CULTURAL FOUNDATION OF THE FACTORY FARM
}

\author{
DAVID N. CASSUTO*
}

The angel went home.

Isaac went home.

Abraham and God had gone long before.

But the real hero of the Isaac story

was the ram. ${ }^{1}$

INTRODUCTION

Over the past several decades, the phrase "animal husbandry" has become more ironic than referential. ${ }^{2}$ The care and upkeep of animals raised for human consumption has devolved into an industrial operation focused on maximizing economic return while paying little or no heed to the needs of the "stock." Though rife with practices that might otherwise invite governmental scrutiny and criticism, industrial agriculture in the United States operates in a regulatory environment that endorses and subsidizes its methods. ${ }^{3}$

\section{Copyright () 2007 by David N. Cassuto}

This article is also available at http://law.duke.edu/journals/lcp.

* Associate Professor of Law, Pace University School of Law. B.A., Wesleyan University, J.D., University of California, Berkeley, Boalt Hall School of Law, Ph.D., Indiana University. My thanks to William Reppy, Isadore Cassuto, Bridget Crawford, and Darren Rosenblum for their comments and suggestions, to Duke Law School for hosting such a provocative and important symposium, and to Julie Mickiewicz and Brenna Zortman for their invaluable research assistance. A very special thank you to Elizabeth Downes and Jesse Cassuto, who made this article possible, better, and worth doing at all.

1. Yehuda Amichai, The Real Hero (excerpted), in The Selected Poetry of YeHUdA AMICHAI 151 (Chana Bloch \& Stephen Mitchell trans., 1986).

2. The term "husbandry" means "bonded to the house," denoting a relationship wherein the interests of the farmer and the animal were linked in a symbiotic union. That symbiosis has become a casualty of the era of industrial farms. They have turned to "animal science" and "meat science," disciplines that have emerged only in the last several decades. MATTHEW SCULLY, DOMINION: THE POWER OF MAN, THE SUFFERING OF ANIMALS AND THE CALl TO MERCY 270-71 (2002). Scully cites Bernard Rollin's observation that "ethics and prudence were closely intertwined: the biblical injunction to rest the animals on the Sabbath expressed both concern for animals and prudence.... Ethics and self interest were organically united." $I d$. This union has long been absent from the landscape of industrial agriculture. See id.

3. See Jim Mason \& Peter Singer, Animal Factories-Revised and Updated 130-33 (1990) (outlining in sections entitled "The Cost of Factory Tax Breaks" and "From Public Interest to Private Gain" how government subsidies to industrial farms have economically strangled small-scale farm operations); The Humane Society Files Suit to End California's Battery Cage Tax Break, http://web.archive.org/web/20060209154118/http://hsus.org/farm_animals/farm_animals_news/hsus_sues _ca_battery_cage_tax_break.html

(last visited Jan. 5, 2006) (summarizing complaint seeking to abolish California's "tax break to factory farms that purchase one of the most abusive confinement devices in modern agribusiness: battery cages for egg-laying hens.”). See also JIM JACOBSON, THE HuMANE SOCIETY OF THE UNITED STATES, THE 
Discussions of the nature of factory farming inevitably include issues of ethical treatment of nonhuman animals and often segue into apologies for or against "animal rights." "This article takes a different tack, asking instead how and why the factory-farm industry could grow ascendant in an era when the notion of the human-animal divide has become increasingly blurred. Contemporary ethological research and philosophical inquiry shows that characteristics that supposedly elevate humans to a privileged ethical position in relation to other creatures are either present in nonhumans or irrelevant for purposes of ethical discourse. In essence, the problem is that "we are not only a little like animals; we are animals."

Consequently, making a biological argument that rights should be confined to humans is challenging on several levels. First, one must locate the biological criterion that definitively separates humans from animals-a problematic endeavor. ${ }^{6}$ Even assuming such a thing could be accomplished, one would then face the equally difficult task of explaining why a biological characteristic should determine access to moral consideration.

On a behavioral plane, distinguishing "humanness" is equally difficult. Not every "human" trait is found in every human. As one commentator notes, "we do not treat possession of distinctively human capacities as a prerequisite for having rights ... we acknowledge that infants, severely retarded and demented people, and other humans who do not have or cannot develop or recover such ... capacities have rights and are entitled to equal consideration."” Furthermore, most every human trait-be it language, tool use, selfconsciousness, or any other-can be found in animals ranging from dolphins to pigeons. ${ }^{8}$

Manure Money Pit: How Environmental Tax Subsidies to Hog Confinements Impact IOWA's COUNTIES (2003) (outlining the way industrial farms enjoy significant subsidies in the form of tax breaks).

4. See, e.g., Peter Singer, Animal Liberation (2002).

5. Mary Midgely, Beast And Man 1 (1979); see also Paula Cavalieri, The Animal Debate: A Reexamination, in IN DEFENSE OF ANIMALS: THE SECOND WAVE 64 (Peter Singer ed., 2006) (laying out an argument based on classical utilitarianism that "if morality is to be coherent, speciesism-that is, discrimination based on species membership—should also be discredited.").

6. As Donna Haraway notes: "Biology and evolutionary theory over the last two centuries have ... reduced the line between humans and animals to a faint trace re-etched in ideological struggle or professional disputes between life and social science." DONNA J. HARAWAY, SIMIANS, CYBORGS, AND WOMEN: THE REINVENTION OF NATURE 152 (1991).

7. Elizabeth Anderson, Animal Rights and the Values of Nonhuman Life, in ANimal Rights: CurRent Debates AND NEW Directions 277, 280 (Martha Nussbaum \& Cass Sunstein eds., 2004).

8. See, e.g., Tom Regan, The CASE FOR ANIMAl Rights 34-81 (1983) (dedicating an entire chapter to "the Complexity of Animal Awareness"); STEVEN WiSE, DrAWING THE LINE: SCIENCE AND THE CASE FOR ANIMAL RIGHTS (2002) (chronicling various capacities of animals ranging from bonobos to honeybees); David Degrazia, On the Question of Personhood Beyond Homo Sapiens, in IN DEFENSE OF ANIMALS: THE SECOND WAVE, supra note 5 at 40, 40-53 (discussing the various cognitive and linguistic capacities of animals); GARY STEINER, ANTHROPOCENTRISM AND ITS Discontents: THE MORAL STATUS OF ANIMALS IN THE History OF WESTERN PHILOSOPHY 18-37 (2005) (summarizing contemporary ethological research in a section entitled "Contemporary Ethology and the Question of Animal Capacities"); JONATHAN BALCOMBE, PlEASURABlE Kingdom: ANIMALS AND THE NATURE OF FEELING GOOD (2006) (arguing that animals experience the emotion 
On the one hand, society seems to recognize the inequities involved in excluding animals from the moral community. On the other, it facilitates industrial agriculture, which has as its goal animals' complete commodification.' These opposing trends and their ability to coexist present a complex social dilemma.

This article argues that the ability of large-scale industrial farms to commodify animals in the face of strong countervailing social forces stems in large part from the legal system's embrace of a secularized but nonetheless deeply religious vision of human ascendancy. Within this belief system, animals comprise beings through whom we define ourselves by contrast and to whom we deny ingress to the legal system. The impulse to increase protections for nonhuman animals is offset by institutionally privileged categories of behavior that commidify nonhumans and strip them of legal defenses. The resulting lattice of laws purports to safeguard animals while instead sanctioning and enabling the practices from which they require protection. ${ }^{10}$

The human-animal dichotomy is no more a "fact" than any other religiously derived norm. Nevertheless, it enjoys a form of constitutional protection seemingly at odds with the Constitution's Establishment Clause. ${ }^{11}$ It further leads to "speciesism," a category of discrimination that makes membership in the privileged species a prerequisite for access to the moral community. ${ }^{12}$

of pleasure in a wide range of activities); JANE GOODALL, IN THE SHADOW OF MAN (2000) (one of her many groundbreaking works on primate behavior).

9. See., e.g., SCULLY, supra note 2, at 253 (2002):

Corporate Farming arose for the same reason all large corporations arise, as men like Donald Tyson, Frank Purdue, and Wendell Murphy realized that animals too, could be produced on an economy of scale in which costs per unit diminished the more units they produced. Mass confinement met vertical integration to provide the cheapest foods for the greatest number in the most efficient way, and consumers rewarded it.

See generally JEREMY RIFKIN, BEYOND BEEF: THE RISE AND FALl of THE CATTLE CUlTuRE (1992) (discussing the emergence of industrial cattle production); Mark Drabenscott, This Little Piggy Went to Market: Will the New Pork Industry Call the Heartland Home?, FED. RES. BANK KAN. CITY ECON. REV., 3rd Quarter, 1998, at 79, 79, available at http://www.kc.frb.org/publicat/econrev/ PDF/3q98drab.pdf (outlining shift in pork production to vertically integrated, highly profitable corporate agribusiness).

10. See Gary Francione, Animals, Property, And the Law 27 (1995) ("[T] he treatment accorded to animals under the law, is determined not by reference to any moral ideal but by the property status of the animal and to what conduct is perceived to maximize the value of animal property.").

11. U.S. CONST. amend. I ("Congress shall make no law respecting an establishment of religion...."). The clause is followed immediately by the Free Exercise Clause ("or prohibiting the free exercise thereof"), with which it exists in delicate counterpoise. As Justice Douglas observed in U.S. v. Ballard,

The Fathers of the Constitution were not unaware of the varied and extreme views of religious sects, of the violence of disagreement among them, and of the lack of any one religious creed on which all men would agree. They fashioned a charter of government which envisaged the widest possible toleration of conflicting views. Man's relation to his God was made no concern of the state. He was granted the right to worship as he pleased and to answer to no man for the verity of his religious views.

322 U.S. 78,87 (1944).

12. The term "speciesism" was originally coined by British psychologist, Richard Ryder. See PAUL WALDAU, THE SPECTER OF SPECIESISM: BudDHIST AND CHRISTIAN VIEWS OF ANIMALS 20 (2002); 
Despite the dominance of the mythic divide between humans and animals and the economic and political ascendancy of factory farms, the discourse of species and its accompanying ethical issues continues to shift. Therein lies the increasing vulnerability of the idea of a singular, dominant species that alone possesses the characteristics necessary for entrance to the moral and legal community. ${ }^{13}$ This fragile notion of human ascendancy as well as the complex social trends undergirding it forms the foundation of this article.

Part II of this article begins with a brief discussion of the factory-farm process and the supportive regulatory environment in which it functions. ${ }^{14}$ It then examines the economic predicates of industrial farming and its lax regulatory scheme. The system assigns worth to nonhumans based only on their exchange value. Humans, on the other hand, enjoy inherent value, which cannot be quantified and which protects them from commodification.

Part III argues that the dominance of industrial farming (and other forms of animal exploitation) derives largely from the ascendancy of a religious belief that has attained a protected status within the legal system. Religion, for purposes of this article, is not an explicitly theistic concept, but rather refers to a system of norms based on hypothesis rather than fact..$^{15}$ The religious principle at issue here is the notion of a morally relevant divide between humans and animals. The supposedly secular explanation of human social evolution offered by Sigmund Freud, wherein he purportedly locates the evolutionary moment when humans separated themselves from animals, brings this myth into stark relief.

JOAN DUNAYER, SPECIESISM 1 (2004); see also, REgAN, supra note 8, at 155 (1983) ("A speciesist position... would take the form of declaring that no animal is a member of the moral community because no animal belongs to the 'right' species—namely, Homo sapiens."); SINGER, supra note 4, at 6 (2002) ("Speciesism . . . is a prejudice or attitude or bias in favor of the interests of one's own species and against those of members of other species.").

13. As Edward.O. Wilson observes,

Those committed by religion to believe that life was put on earth in one divine stroke will recognize that we are destroying the Creation, and those who perceive biodiversity to be the product of blind evolution will agree. Across the other great philosophical divide, it does not matter whether species have independent rights or conversely, that moral reasoning is a uniquely human concern. Defenders of both positions seem destined to drift toward the same position on conservation.

THE DIVERSITY OF LIFE 351 (1992).

14. Here and throughout this article, the term "factory farms" is used interchangeably with industrial farms or industrial agriculture.

15. See United States v. Seeger, 380 U.S. 163, 184 (1965) (opining that, for purposes of qualifying for a religious exemption from military service, the test for whether a belief is religious is "essentially an objective one, namely, does the claimed belief occupy the same place in the life of the objector as an orthodox belief in God holds in the life of one clearly qualified for exemption [from military service]?"). In Welsh v. United States, 398 U.S. 333, 344 (1970), the Court expanded its definition to include the views of a defendant claiming conscientious-objector status based on his "beliefs" rather than his "religious beliefs." Justice Harlan, concurring in the judgment, complained that the Court seemed to be embracing a "secular definition of religion." Id. at 353 (Harlan, J., concurring). See also Anand Agnoshwar, Note, Rediscovering God in the Constitution, 67 N.Y.U. L. REV. 295, 319 (1992) (citing Welsh and explaining that the Seeger standard is "based on supernatural assumptions [and] envisions that citizens often will act virtuously out of duty to their religion ... and is appropriate for both free-exercise and establishment cases."). 
Part IV discusses the quasi-constitutional status enjoyed by the humananimal divide. It uses a case study of the 1993 Supreme Court decision in Church of Lukumi Babalu v. City of Hialeah ${ }^{16}$ to illustrate this phenomenon. Lukumi centered on a dispute between the city of Hialeah, Florida, and a Santería church that wished to carry out animal sacrifices within city limits. The Court struck down the city ordinances barring animal sacrifice, holding that they violated the Free Exercise Clause of the First Amendment. ${ }^{17}$ By protecting animal sacrifice as a First Amendment right, the Court embraced the idea that nonhuman animals are subjects of rather than participants in the legal system and that their well-being is subordinate to human desires.

This principle of humans as separate and distinct from animals is derived from and dependent on a fundamentally religious belief. It enables the fetishization of animals, either as commodities (as in factory farms) science experiments (biomedical research) or objects of ritual (animal sacrifice). Therefore, though Lukumi has no overt relationship to industrial farming, its reasoning nevertheless provides a powerful legal and cultural explanation for practices that subjugate and commodify nonhuman animals.

Lukumi's reasoning shows how animal subjugation as a matter of right has been woven into the framework of the nation's laws. Effectively addressing the problems of factory farms-and other problematic forms of animal exploitation-will involve unraveling a tightly woven cultural quilt. It will require eschewing the unworkable notion of a human-animal divide and instead constructing a rhetoric of the "posthuman." Part V of this article represents my attempt to begin that process.

II

\section{THE FACTORY-FARM FOUNDATION}

\section{A. The Factory Environment}

The animal-production process results from a legal and regulatory environment designed to facilitate animal-based wealth acquisition. This relationship has been well-documented elsewhere and need not be replicated here. ${ }^{18}$ The following overview serves only to illustrate the contention that industrial agriculture occupies a privileged place in the legal and regulatory scheme.

16. 508 U.S. 520 (1993).

17. Id. at $546-47$.

18. See, e.g., David J. Wolfson \& Mariann Sullivan, Foxes in the Hen House: Animals, Agribusiness, and the Law: A Modern American Fable, in Animal Rights: Current Debates And New DIRECTIONS, supra note 7, at 205 ; Jim Mason \& Mary Finelli, Brave New Farm, in IN DEFENSE OF Animals: THE SECOND WAVE supra note 5, at 104, 120-21; Clare Druce \& Philip Lymbery, Outlawed in Europe, in IN DEFENSE OF ANIMALS: THE SECOND Wave , supra note 5, at 123, 123-31; Mason \& Singer, supra note 3, at 135-59 (entitled "Factory Agribusiness: The Farmer as Victim or Who's Making the Real Money?"). 
Factory-farm conditions vary depending on the species and the desired product. The common denominator, however, is an almost single-minded focus on economic yield. Chickens, for example, might be "broilers" or egg producers. The nature of their confinement and length of their life depends on their designated function.

Egg producers must be female, so all male chicks are destroyed shortly after birth. ${ }^{19}$ The females are debeaked,$^{20}$ toe-clipped, and housed in a "grow-out" facility until they reach egg-producing age. They are then moved to the laying facility and stacked in wire "battery" cages, three to ten birds to a cage, with each cage measuring less than two feet square. Often, several hundred thousand birds occupy one building, stacked in cages eight tiers high. The cages have sloped floors so that eggs can roll out of the cages on to a belt to be then carried off for processing. Severely overcrowded conditions, wire floors, continuous confinement and the rigors of accelerated egg production ${ }^{21}$ cause the hens' productivity to plummet after roughly a year. They are then destroyed.

If designated as broilers, chicks (both male and female) are debeaked and toe-clipped ${ }^{22}$ and then packed by the tens of thousands in enormous sheds. After roughly six weeks of intense, overcrowded conditions on floors coated with manure and urine, during which time they constantly inhale the by-products of their waste, the birds reach market weight of approximately four pounds. ${ }^{23}$ They are then packed into crates and sent to slaughter. ${ }^{24}$

Poultry producers aspire to create a battery-cage system for broilers but have not yet overcome problems including breast blisters, bruises, and excess abdominal fat. ${ }^{25}$ Nevertheless, the industry aims to create a system wherein cage production becomes the norm. As one producer visualizes it, chicks in cages

19. Methods of slaughter vary. Often the chicks are ground up alive, gassed, or thrown into large dumpsters to suffocate. Nicole Fox, The Inadequate Protection of Animals Against Cruel Animal Husbandry Practices Under the United States Law, 17 WhitTIER L. REV. 145, 151 (1995); See Barbara O'Brien, Animal Welfare Reform and the Magic Bullet: The Use and Abuse of Subtheraupeutic Doses of Antibiotics in Livestock, 67 U. COLO. L. REV. 407, 417 (1996).

20. Debeaking involves using a hot blade to slice off the beak of a young chick. This procedure involves no anesthesia and is quite painful. Debeaked chickens have trouble grasping and swallowing feed. See Mason \& Singer, supra note 3, at 39-40. Poultry producers claim this procedure is necessary to reduce feed costs as well as to deter "aggressive tendencies" (a euphemism for cannibalism) among the closely confined birds. Id. at 2-3. See also O'Brien, supra note 19, at 416; Fox, supra note 19, at 151.

21. Since 1940, egg production per chicken has doubled, from roughly 130 eggs per year to 260 . This is a result of both genetic manipulation and techniques, including "forced molting," designed to maximize egg production, http://www.hsus.org/farm/resources/research/welfare/egg_industry.html (last visited May 6, 2006) (explaining that birds naturally molt in the fall when daylight hours gradually wane. Due to less sunshine, the available food supply decreases, and birds eat less, thereby ceasing egg production. Forced molting involves the abrupt withdrawal of food. The sudden starvation "shocks the hen" and shuts down reproduction. The post-molten period results in high reproduction. However, animals are motivated by hunger. The cramped confinement of the battery cages results in aggression. Additionally, forced starvation weakens the hens' immune systems, resulting in the need for antibiotics.)

22. O'Brien, supra note 19, at 415.

23. See id.

24. See MASON \& SINGER, supra note 3, at 6.

25. Id. at 7. 
would be placed on a conveyer belt and transported into a confinement facility and then emerge on the other end as a finished broiler. ${ }^{26}$

Other animals raised for food face analogous conditions. Pigs are confined in pens so small they cannot turn around or groom themselves. Soon after birth, their tails are amputated, their teeth clipped, their ears notched, and males are castrated-all without anesthesia. Upon reaching breeding age, females are inseminated and then confined for months at a time in "gestation crates" too small to permit foraging or nest building. Shortly before birthing, they are transferred to a "farrowing crate" designed to prevent all activity except eating, drinking, and keeping teats exposed to the piglets. ${ }^{27}$ When the piglets are forcibly weaned after roughly nineteen days (fifty-six days is the norm under non-factory conditions) ${ }^{28}$ the breeding cycle begins again for the sows. ${ }^{29}$ When the sows become too weak to gestate, they are killed. ${ }^{30}$

The rigors suffered by chickens and pigs are not specific to their respective species. Cattle, rabbits, sheep, and all other animals raised under industrial farming conditions face similar travails. ${ }^{31}$ The laws regulating the factory-farm industry offer little protection to the factory-farm products.

1. Federal Laws Are Sparse and Ineffectual

The Animal Welfare Act, ${ }^{32}$ the principal federal statute mandating protections for animals and setting standards for their care, specifically excludes farm animals from its ambit. ${ }^{33}$ Without an umbrella statute under which to regulate, the U.S. Department of Agriculture (USDA) cannot promulgate regulations to safeguard the health and well-being of food animals. ${ }^{34}$ Even if the USDA could regulate the industry, it has shown little interest in doing so. ${ }^{35}$

In addition, the Humane Slaughter Act, ${ }^{36}$ enacted to protect livestock from the often agonizing deaths that awaited them at industrial slaughterhouses, mandates that livestock be slaughtered using "humane methods." ${ }^{37}$ However,

26. Id.

27. See O'Brien, supra note 19, at 419.

28. Mason \& Finelli, supra note 18, at 114. Smithfield actually weans its piglets in seven to ten days. See SCULLY, supra note 2, at 275.

29. Mason \& Finelli, supra note 18, at 108-09.

30. See SCULLY, supra note 2, at 269.

31. See generally MASON \& SINGER, supra note 3, at 1-15.

32. Animal Welfare Act of 1970, 7 U.S.C. $\S \S ~ 2131-2147,2149,2150,2155$ (1970). Six years later, Congress passed the Animal Welfare Act Amendments of 1976, Pub. L. No. 94-279, 90 Stat. 417 (codified as amended in scattered sections of 7 U.S.C.) [hereinafter Animal Welfare Act].

33. 7 U.S.C. $\$ 2132(\mathrm{~g})$.

34. See Wolfson \& Sullivan, supra note 18, at 207.

35. See Valerie Stanley, The Animal Welfare Act and USDA: Time for an Overhaul, 16 PACE ENVTL. L. REV. 103 (1998).

36. Humane Methods of Slaughter Act of 1978, Pub. L. 95-445, 92 Stat 1069 (codified in scattered sections of 7 U.S.C.).

37. 7 U.S.C. $\$ 1902$ (2000). Jeff Welty, Humane Slaughter Laws, 70 LAW \& CONTEMP. PROBS. 175, 183 (Winter 2007). 
the USDA has determined that the term "livestock" as used in the Act $^{38}$ excludes poultry. ${ }^{39}$ Thus, the billions of chickens, turkeys, and ducks (as well as fish) slaughtered every year need not be-and usually are not-rendered insensible to pain before being hoisted, shackled, and cut. ${ }^{40}$ In addition, the statute exempts ritual slaughter as well as state-inspected slaughterhouses from oversight. ${ }^{41}$

\section{State Laws Are Likewise Unproductive}

Twenty-eight states have anticruelty statutes that specifically exempt farming practices that are generally accepted in the industry. ${ }^{42}$ This exemption effectively strips the laws of any force or normative component. Standard industry practices are typically those that best serve the industry. Removing those practices from legal scrutiny enables regulated entities to tailor their practices to their maximum benefit, regardless of societal standards or impact on the affected animals.

State criminal anti-cruelty statutes have proven ineffective for several reasons. First, the state must prove intent, a task complicated by the enormous number of animals processed by industrial food producers. ${ }^{43}$ Given the hundreds of thousands of animals in their custody, producers can easily claim that they did not know the condition of any given animal. Thus, indifference to the animals' well-being actually becomes a defense to prosecution. ${ }^{44}$

Furthermore, criminal statutes do not spawn regulations. Without guidelines for the industry or an administrative agency tasked with the laws' enforcement, no regular inspections take place. This means the job falls to local law-

38. 7 U.S.C. $\S 1901$.

39. Id.; 9 CFR $\$ 301.2$ (2006); see Still A Jungle Out There: The HSUS takes USDA to Court to Ensure a Humane End for Birds, http://www.hsus.org/farm_animals/farm_animals_news/still_a_jungle_ out_there.html; see also Geoffrey S. Becker, Humane Treatment of Farm Animals: Overview and Issues, CRS Report RS21978 (2005), available at http://www.opencrs.com/document/RS21978/.

40. As a practical matter, this means that more than ninety-eight percent of animals slaughtered for food are exempt from the protections of the Act. Gaverick Matheny \& Cheryl Leahy, Farm-Animal Welfare, Legislation, and Trade, 70 LAW \& CONTEMP. PROBS. 325, 335 (Winter 2007); Mason \& Finelli, supra note 18 , at 120.

41. David J. Wolfson, Beyond the Law, 2 AnIMAL. L. 123, 126 (1996); see generally Tali H. Shaddow, Religious Ritual Exemptions: Sacrificing Animal Rights for Ideology, 24 LOY. L.A. L. REV. 1367 (1991).

42. Other states, including Maine, North Carolina, Ohio, Vermont, and Wisconsin, exempt specific industry practices from regulatory scrutiny. Still others, including Louisiana and South Carolina, exempt specific animals (in this case, birds) from state protection. See Wolfson, supra note 41, at 137; William A. Reppy, Broad Exemptions in Animal-Cruelty Statutes Unconstitutionally Deny Equal Protection of the Law, 70 LAW \& CONTEMP. PROBS. 255, 307-23 (Winter 2007).

43. See Wolfson \& Sullivan, supra note 18, at 209; see also Paula J. Frosso, The Massachusetts AntiCruelty Statute: A Real Dog-A Proposal for a Redraft of the Current Law, 35 NEW ENG. L. REV. 1003 (2001) (providing an overview and analysis of the effectiveness of animal-cruelty laws in the United States).

44. See, e.g., Wolfson \& Sullivan, supra note 18, at 209 (citing State of New Jersey v. ISE Farms, Inc. (Sup. Ct. Warren Co., N.J. Mar. 8 2001) (unreported decision on the record) (vacating conviction for animal cruelty because the hundreds of thousands of chickens owned by defendant and the few people actually responsible for them meant that the two sick but still living chickens found in a garbage bin full of dead chickens might not have been "knowingly" discarded). 
enforcement officials who, absent a search warrant, cannot enter private property to ensure compliance..$^{45}$ Even if they could enforce the statutes, these officers would have little incentive to do so; penalties for violations are generally quite low. ${ }^{46}$

The low penalty for violations of animal-cruelty statutes indicates a low societal interest in deterring the behavior. This lack of interest in protecting the animals from harm stems from the fact that their value is often enhanced through their mistreatment (in the sense that the less money invested in their welfare, the greater the profit realized from their sale).

\section{B. The Nature of Value-Dual \& Dueling Definitions}

\section{Inherent Value-The Human Domain}

An object's value within society can take two primary forms. Inherent value confers (or requires, depending on one's epistemological orientation) membership in the moral community. ${ }^{47}$ As an "experiencing subject of a life," one possesses legal protections that are objective, permanent, and incontrovertible. $^{48}$ These are the inalienable rights immortalized in the Declaration of Independence. ${ }^{49}$

As possessors of inherent value, members of the moral community enjoy a panoply of rights-legal entitlements that others are bound to respect and for

45. See id. at $209-10$.

46. Id. at 210 .

47. This orientation is based on a natural law rather than a positivist viewpoint. This article does not argue for the superiority of the natural law position, only that its notion of human ascendancy forms the plinth of our legal and social systems. See FrAnCIONE, supra note 10, at 95 (taking similar tack); Rebecca J. Huss, Valuing Man's and Woman's Best Friend, The Moral and Legal Status of Companion Animals, 86 MARQ. L. REV. 47, 65-66 (2002) (explaining that each individual "has a moral right to be treated as having individual value.").

48. See REGAN, supra note 8, at 243-50, especially 243 (laying out the idea of a subject of a life as the dispositive factor in allocating rights and articulating what he calls the "respect principle" for all subjects of a life: "We are to treat those individuals who have inherent value in ways that respect their inherent value."). According to Regan, individuals are subjects of a life if

they are able to perceive and remember; if they have beliefs, desires, and preferences; if they are able to act intentionally in pursuit of their desires or goals; if they are sentient and have an emotional life; if they have a sense of the future, including a sense of their future; if they have a psychophysical identity over time; and if they have utility for, and the interests of, others.

Id. at 264 .

49. Specifically, the passage reads, "We hold these truths to be self-evident, that all men are created equal, that they are endowed by their Creator with certain unalienable Rights, that among these are Life, Liberty and the pursuit of Happiness." THE DECLARATION OF INDEPENDENCE (U.S. 1776). As a practical matter, rights are far from inalienable. In a passage entitled "Race Thinking Before Racism," Hannah Arendt cites Edmond Burke's contention that the rights of Englishmen were not based on any inherent human entitlement but rather on the specific achievements of a specific people. HANNAH ARENDT, THE ORIGINS OF TOTALITARIANISM 175-76 (1973). Thomas Jefferson wrote the Declaration precisely because, in his view, King George had alienated the colonists from those rights enjoyed by other British subjects. Abraham Lincoln carried off a similar rhetorical legerdemain in the Gettysburg Address, when he argued that the nation's founders had created a country where "all men are created equal." Abraham Lincoln, The Gettysburg Address (Nov. 19, 1863). 
whose violation there is recourse under the law. ${ }^{50}$ Kant describes such rightsholders as ends in themselves rather than means to the ends of others. ${ }^{51}$ As rights-holders, members of the moral community can invoke the power of the state to enforce and protect their interests.

For Kant, only humans comprise ends in themselves and thus only they enjoy the rights that accompany membership in the moral community. ${ }^{52}$ In recent years, the penumbra of rights has expanded incrementally and now arguably extends to some types of animals under certain circumstances. ${ }^{53}$ For example, the Endangered Species Act $^{54}$ allots members of threatened and endangered species with legal protections that others are bound to respect. Similarly, the Animal Welfare Act ${ }^{55}$ codifies legal protections for animals, as does the Humane Slaughter Act. ${ }^{56}$ However, these laws exempt more animals than they protect. ${ }^{57}$ Furthermore, because they are statutory and therefore

50. See, e.g., FRANCIONE, supra note 10, at 95 ("A legal right is a right that is recognized and enforced by the legal system."); Huss, supra note 47, at 66.

51. See Immanuel KANT, LeCtURes ON ETHICs 239-40 (Louis Infield trans., Harper Press 1963) (1775-1780) (declaring that animals are "man's instruments" who "are there merely as a means to an end. That end is man.").

52. Steiner lucidly analyzes Kant's human-animal distinction. STEINER, supra note 8, at 166-71, especially 168-69. Kant defines humans as "persons," that are ends in themselves, and animals as "things"- "mere means for the satisfaction of higher [human] ends." In Kant's view, human capacity for rationality and self-improvement leads inexorably to the conclusion that the only possible purpose of the world is "man under moral laws." Id. at 168 (quoting Kant).

53. Some commentators argue that these statutes do not confer rights as such, but rather protect animal interests that dovetail with human ends. See, e.g., Gary FrancIONE, Animals-Property or Persons, in ANIMAl Rights: CURRENT DEBATES AND NEW DiReCTIONS, supra note 7, at 108, 131 (arguing that animals are either "beings to whom the principle of equal consideration applies ... or things, beings to whom the principle of equal consideration does not apply and whose interests may be ignored if it benefits us."); cf. Cass Sunstein, Standing for Animals (With Notes on Animal Rights), 47 UCLA L. REV. 1333, 1362-66 (2000) (noting that since some animals currently possess a range of legally enforceable claims, as a legal matter, they therefore possess a recognizable form of rights); David Favre, Integrating Animal Interests into Our Legal System, 10 ANIMAL L. 87, 93 (noting that the adoption of the Uniform Trust Act of 2000 by many states allows pets to become beneficiaries of trusts, which grants them a form of legal personhood even as they are still considered property). John Rawls argues that humans have direct moral duties of "compassion and humanity" to animals but that these duties do not fall within his contractarian theory of justice because animals lack those innate qualities "in virtue of which they are to be treated in accordance with the principles of justice." JOHN RAWLS, A THEORY OF JUSTICE 504, 512 (1971). Rawls' theory relies on the possession of human rational faculties as a prerequisite for membership in the moral community. As discussed infra in Part IV, I believe this view is unnecessarily exclusionary. See also Martha C. Nussbaum, Beyond 'Compassion and Humanity': Justice for Nonhuman Animals, in ANIMAL Rights: CURRENT DEBATES AND NEW DiReCTIONS, supra note 7, at 299, 300-02 (offering a similar critique); J. BAIRD CALLICOTT, IN DEFENSE OF THE LAND ETHIC: ESSAYS IN ENVIRONMENTAL PHILOSOPHY 71 (1989) (refuting notion that mutual obligations or common interests are preconditions to membership in the moral community).

54. 16 U.S.C. $\S \S 1531-1544$ (2000).

55. Animal Welfare Act, supra note 32.

56. Humane Methods of Slaughter Act of 1978, Pub. L. No. 95-445, 92 Stat. 1069 (codified in scattered sections of 7 U.S.C.) [hereinafter Humane Slaughter Act].

57. See infra note 32 and accompanying text. The Endangered Species Act seeks to protect only species threatened with extinction. The other statutes have broader mandates but are riven with exemptions that undermine their effectiveness. Wolfson \& Sullivan, supra note 18, at 206 (noting that the vast majority of nonhuman animals with whom humans interact are raised for food and that "as a practical matter, farmed animals have no legal protection at all"). 
subject to repeal or amendment, they lack the permanence of truly inherent rights and therefore do not enable real access to the moral community.

\section{Exchange Value-Commodified Beings}

The counterpode to inherent value is exchange value, a worth that is neither innate nor imbued with accompanying rights. Exchange value defines an object's transactional worth in a market economy. ${ }^{58}$ The object functions as a medium of exchange through which others (not the object) accomplish an objective. It stands to reason that the object of exchange possesses no inherent, objective value since its value is acquired through its worth to others. ${ }^{59} \mathrm{~A}$ commodity possesses no rights; it serves as a means to the ends of others rather than an end in itself. It follows, therefore, that an assigned exchange value necessitates exclusion from the moral community.

Objects with exchange value are things. ${ }^{60}$ Exchange value can and often does lead to fetishization as an object's increased market worth enriches its owner. In this respect, as Marx noted, a thing "change[s] into something transcendent" when "it steps forth as a commodity." ${ }^{\circ 1}$ This transcendence takes shape as an inverted form of reverence. An object's market value increases with marketability leading to an increased desire to alienate it. The greater an object's value, the greater the temptation to divest oneself of it. Thus, the realities of the marketplace make it both difficult and counterproductive to form a relationship with a commodity, a fact that further facilitates objectification. In the case of animals, it also enables mistreatment.

In the industrial-farm context, animals and animal by-products comprise the "things" at issue. Their commodification confers an exchange value that, in the case of "meat" animals, is realized through death and dismemberment. For animal producers (milk cows, breeding sows, et cetera), value emerges through maximizing productivity while minimizing costs. In neither instance does the animals' quality of life enter the equation. Rather, in both cases, the economic incentive-which is, after all, what drives exchange value-lies with minimizing expenses associated with the thing while maximizing its yield. ${ }^{62}$ It is easy to see

58. See The MARX-Engels ReAder 208 (Robert Tucker ed., W.W. Norton \& Co., 2d ed. 1978) (quoting from Karl Marx's published paper, Wage, Labor and Capital, "[Things] which are exchangeable for others are commodities. The particular ratio in which they are exchangeable constitutes their exchange value ...."); see also Doug Litowitz, Reification in Law and Legal Theory, 9 S. CAL. INTERDIS. L.J. 401, 406 (2000) (explaining that an object's value is not measured by its physical properties, but "instead [it is] pure exchange value in a sense that [it] only [has] value" in a social system where it can be traded).

59. Litowitz, supra note 58, at 407.

60. See, e.g., Slaughter-House Cases, 83 U.S. 36, 127 (1872) (Swayne, J., dissenting) ("Property is everything which has an exchangeable value."); Chicago, Milwaukee \& St. Paul Ry. Co. v. Minn., 134 U.S. 418, 458 (1890) (explaining that property is not just a thing, but is also exchange value).

61. See W.J.T. Mitchell, Introduction to CARY Wolfe, Animal Rites: AMERICAN CUlture, THE DisCOURSE OF SPECIES, AND POSTHUMANIST THEORY xii (2003) (quoting Marx).

62. See Francione, supra note 10, at 27; Robyn Mallon, The Deplorable Standard of Living Faced by Farm Animals in America's Meat Industry and How to Improve Conditions by Eliminating the Corporate Farm, 9 MiCH. STATE UNIV. J. OF MED \& L. 389, 399 (2005). 
how this logic leads to factory farms designed to maximize economic efficiency regardless of the impact on animals. It also catalyzed the industry's vertical integration. As a result, a few large conglomerates now control the animalproduction process "from squeal to meal."

Classification as a thing also exempts objects from any moral calculus. Exchange value is amoral; it is a function of demand. Owners maximize value through increasing marketability. Moral arguments as to the market value of things carry little practical weight because the two systems (moral and market) do not share a common mode of valuation. ${ }^{64}$

Things (as opposed to persons) acquire legal protections only if that protection serves the purposes of the rights-holders. ${ }^{65}$ It follows that things can be sacrificed if that sacrifice will benefit the rights-holders. This latter principle informs the case of Lukumi Babalu. ${ }^{66}$ And within such a framework, the Court's decision to protect animal sacrifice as a form of expression is entirely logical. So too is the treatment of industrial farm animals. In this sense, the animal sacrifice that forms a part of religious practices differs little from the animal sacrifices of the market economy.

In both contexts, human owners alienate valued commodities in the hopes of advancing their material condition. With religious sacrifice, the idea is to please the gods and thereby improve one's lot. In a market economy, one sacrifices possessions while looking to increase material wealth and economic station. In both instances, the sacrificial object functions as a means to an end, which in turn relegates it to the status of thing. ${ }^{67}$ Also, in both systems, the laws are designed to enable the transaction.

63. Smithfield Foods, the world's largest vertically integrated producer of pig products, proudly embraces both the term and the concept. This quotation, from Lewis Little, president of Smithfield's largest subsidiary, appears in the company's promotional material. See Understanding Smithfield, http://web.archive.org/web/20060112014547/http://www.smithfieldfoods.com/Understand/Vertical/ (last visited Jan. 7, 2007).

64. See FRANCIONE, supra note 10, at 27 ("[O]ur allocation to humans of rights in the bodies of animals reflects the notion that it is more efficient to relegate animals to property status ... than it is to value animals for themselves and to accord them dignity and respect. Moral concern for animals is not a cost-justified policy.").

65. See supra RAWLS note 53, at 504, 512 (offering a different vision wherein animals are owed "duties of compassion and humanity" but not justice).

66. See infra note 85 and accompanying text.

67. The relegation of the sacrificial item to the realm of things forms one of the most jarring aspects of the biblical narrative wherein God requires that Abraham sacrifice his son, Isaac. See Genesis 22:2 (King James). Rather than force Abraham to give up something of exchange value, God instead orders that he sacrifice something of inherent value-his child. This involved sacrificing an end in order to achieve another end, an ethically insupportable demand. For this reason, the request shocked not only the conscience but the social system. The idea of human sacrifice as anathema and evil is also present in the legend of Tophet. Tophet was the original name of a place near Gehanna, south of Jerusalem, where Jews supposedly committed acts of human sacrifice to strange gods. Later it became symbolic of the torments of Hell. See OXFORD ENGLISH DICTIONARY (2d ed. 1989); see also Gideon Bohak, Classica et Rabbinica I: The Bull of the Phalaris and the Tophet, 31 J. STUD. JUDAISM, XXXI 203, 211-16 (2000) (explaining that the legend of Tophet has mutated through classical literature, yet this mutation continues to incorporate many of the same elements-a society sacrificing children at the beacon of a God whom they feared, ultimately sacrificing their own children for the sole purpose of allaying those fears and acquiring nothing more); $c f$. Yannis Hamilakis \& Eleni Konsolaki, Pigs for the 
III

\section{The Culture of "SPECIES"}

The human-animal distinction that drives the factory-farm apparatus requires that humans define themselves through contrast, thereby establishing humanity as a species apart from all others. However, the ethological and ethical predicates for this self-definition reveal a pattern of norms predicated on faith. Stated more directly, the human-animal distinction is a religious principle - in the sense that it rests on unsubstantiated belief rather than factand should be treated as such under the law. Here, I refer not just to the traditional "dominion" rhetoric that infuses western religious traditions, but also to the underlying idea that humans are somehow separate and distinguishable from animals. ${ }^{68}$ This human-animal distinction is well established in secular scientific discourse as well, ${ }^{69}$ as, for example, in Freud's vision of human evolution.

In Civilization and Its Discontents, Freud describes the emergence of humans as an act of "organic repression." ${ }^{\text {"70 }}$ Humanity resulted when our simian forebears began walking upright and discovered that blood and feces-once the primary attraction of life at ground-level-had lost its allure. Freud attributes this to a "diminution of olfactory stimuli," making what was once sexually exciting into something disgusting. ${ }^{71}$

With the demotion of smell, sight emerged as the privileged sense. Freud believed that since sight is less linked to one's immediate physical environment (that is, one can focus more easily on things far away), its dominance spurred the development of aesthetic sense and contemplative distance. These characteristics, perceived as quintessentially human, led to the emergence of

Gods: Burnt Animal Sacrifices as Embodied Rituals at a Mycenaean Sanctuary, 23 OXFORD J. OF ARCHAEOLOGY 135, 145 (2004) (explaining that "meat is an expensive commodity to produce and also involves killing of the animal....[Therefore,] the offering of part of the animal to the deities operates as a purification ritual which justifies the violence involved... as necessary, and represents the consumption of a valuable and rare commodity as an expense shared with the deities.").

68. Within the last century, the biblical notion of man's dominion over animals was an acceptable legal argument relied on by courts. See People ex. rel. Freel v. Downes, 136 N.Y.S. 440, 445 (Magistrate Ct. 1911) ("By biblical mandate man was given "dominion over ... the whole earth and every creeping creature that moveth upon the earth."'); U.S. v. Atlantic Coast Line R. Co., 173 F. 764, 766 (4th Cir. 1909) (noting that "[i]t is true that, by virtue of Divine authority, [animals] are under the dominion and control of man"). While vestiges of this view continue to inform legal analysis, more important for purposes of this article is that the distinction between humans and animals has been embraced as a secular and "scientific" fact.

69. As Haraway points out,

The degree to which the principle of domination is deeply embedded in our natural sciences, especially in those disciplines that seek to explain social groups and behavior, must not be underestimated. In evading the importance of dominance as a part of the theory and practice of contemporary sciences, we bypass the crucial and difficult examination of the content as well as the social function of science.

HARAWAY, supra note 6 , at 8.

70. Sigmund Freud, Civilization AND ITs Discontents 53 n.3 (James Strachey ed. \& trans., W.W. Norton \& Co. 1962) (1930).

71. Id. 
human civilization. ${ }^{72}$ This evolutionary journey also catalyzed sexual repression as well as a cultural and evolutionary shift toward cleanliness. First the family unit and then human civilization emerged from these conjoined phenomena. ${ }^{73}$

Yet, Freud's neo-Darwinist theory of evolution is fundamentally illogical because "the human being, who becomes human only through an act of 'organic repression,' has to already know, before it is human, that the organic is repulsive and needs to be repressed." ${ }^{74}$ In other words, the act of becoming human requires an already intact human sensibility. This makes what Freud proffers as an organic evolutionary truth into an act of post-hoc self-definition. And that self-definition involves defining humanity in contrast to a created animalother. $^{75}$

As the circularity of Freud's origin myth becomes evident, so too can we see that defining nonhuman animals through their predilection for filth and asocial behavior has certain advantages. It forms a convenient method of maintaining the human-animal distinction in an age in which that distinction appears increasingly suspect. This tactic proves especially useful for industrial farms.

For example, warehousing vast quantities of animals in close confinement often forces them to wallow in excrement. ${ }^{76}$ It also puts the animals in stultifying, close proximity while depriving them of sensory stimuli. ${ }^{77}$ The confinement creates a constant need for infusions of antibiotics, amputations, and genetic manipulation in order to ward off disease and mayhem. ${ }^{78}$ In other words, factory-farming turns animals into "animals," a problem solved through human intervention. The goal is to create sterile, pink "meat" with a pleasing flesh-to-fat ratio that soothes the aesthetic sensibilities of the human endconsumer. $^{79}$

72. See Wolfe, supra note 61, at 2 (the analysis of Freud here draws heavily on Wolfe's excellent work, which explains the link between civilization, aesthetic sense, and contemplative distance).

73. The vision of cleanliness as a plinth of civilization retains considerable currency. Martha Nussbaum notes that William Miller, "following ... Norbert Elias, argues that the more things a society recognizes as disgusting, the more advanced it is in civilization... [T] he more we focus on cleanliness and the more intolerant we become of slime, filth, and our own bodily products, the more civilized we are." Nussbaum finds this claim "utterly unconvincing, both descriptively and historically." MARTHA C. Nussbaum, Hiding From Humanity: Disgust, SHAME AND THE LAW 115 (2004).

74. WOLFE, supra note 61, at 2-3.

75. See HARAWAY, supra note 6, at 11 (arguing that animals played an important role in the project of "human engineering" by, among other things, "show[ing] people their origin, and therefore their pre-rational, pre-management, pre-cultural essence.").

76. This is particularly true in the poultry industry. See supra note 21 and accompanying text; see also SINGER, supra note 4, at 104-05 (noting that broiler chickens are confined for weeks at a time in windowless sheds "charged with ammonia, dust and microorganisms" which damage the birds' lungs, ulverate their feet, and cause breast blisters and hock burns).

77. See generally MASON \& SINGER, supra note 3; SCULLY, supra note 2, at 247-86.

78. See Mallon, supra note 62, at 399 (outlining the need for antibiotics in confined animal operations).

79. Jacques Derrida aptly sums up this self-reinforcing and self-serving distinction when he notes in The Animal That Therefore I Am (More to Follow) that

traditional forms of treatment of the animal have been turned upside down by the joint developments of zoological, ethological, biological and genetic forms of knowledge and the always inseparable techniques of intervention ... by means of farming and regimentalization 
In this manner, factory farming reinforces both sides of Freud's humananimal binary. It creates filth-laden, violent conditions in which nonhuman animals dwell while shaping human demand for uniform, standardized meat products. ${ }^{80}$ The impression created is one in which animals dwell in filth and violence and humans possess a delicate aesthetic sense satisfied through subjugating and commodifying the animals. Viewed from this vantage, the durability of the human-animal distinction begins to make sense. ${ }^{81}$ And, given the myriad benefits of this arrangement for humans, it seems further clear why that distinction would enjoy a favorable regulatory environment.

\section{IV}

\section{WHY FACTORY FARMS HAPPENED}

We have examined the socio-cultural apparatus that explains how industrial farms grew ascendant but have not fully explored the why. Clearly, the humananimal distinction occupies a privileged place in the American myth structure and legal landscape. However, it is not as obvious why the distinction has proved so resilient. At least part of the answer resides with the constitutional protections afforded to religious expression.

If the human-animal distinction is a fundamentally religious precept, ${ }^{82}$ (albeit one now firmly ensconced in secular discourse) then the Establishment Clause should prevent it from forming the basis for any legal framework. As Ronald Dworkin observed, "religion must observe the principles of democracy, not the other way around." ${ }^{\prime 3}$ Yet, courts (including the Supreme Court) unquestioningly accept animals' exclusion from the moral community. ${ }^{84}$ The best illustration for the reasoning underlying this phenomenon lies in the Lukumi Babalu case.

at a demographic level unknown in the past, by means of genetic experimentation, the industrialization of what can be called the production for consumption of animal meat, artificial insemination... more and more audacious manipulations of the genome, the reduction of the animal not only to production and overactive reproduction (hormones, crossbreeding, cloning, etc.) of meat for consumption but also of all sorts of other end products, and all that in the service of a certain being and the so-called human well-being of man.

28 CRITICAL INQUIRY 394 (2002); see also WOLFE, supra note 61, at 77 (quoting same).

80. See RIFKIN, supra note 9, at 96-97 (discussing how the USDA grading system favors corn-fed meat, a process favored by industrial farms and which works to the detriment of small farmers).

81. Haraway argues that the social relationships of production and reproduction create a "union of the political and physiological," which leads to a culture of domination, "especially domination based on differences seen as natural, given, inescapable, and therefore moral." HARAWAY, supra note 6, at 78 .

82. See supra note 67 and accompanying text.

83. Ronald Dworkin, The Right to Ridicule, N.Y. REV. OF Books, Mar. 23, 2006, at 44.

84. Exclusion from the moral community translates-in the legal realm-into a lack of enforceable rights. Courts have routinely held that since animals are not "persons" under the law, they lack standing to sue and therefore lack a legal remedy when they are wronged. See, e.g., Cetacean Cmty. v. Bush, 386 F.3d 1169, 1176-79 (9th Cir. 2004) (construing personhood under various statutes including the Endangered Species Act, the Marine Mammal Protection Act, and the Administrative Procedure Act to exclude nonhuman animals). 


\section{A. Lukumi Babalu}

The facts and procedural history of Church of the Lukumi Babalu Aye, Inc. v. City of Hialeah ${ }^{85}$ are fairly straightforward. The petitioner was a Santería church. ${ }^{86}$ Central to the Santería faith and practice are deep, personal relationships with "orishas," spirits who help believers fulfill their destinies. The relationship between the Santería faithful and orishas is nurtured through animal sacrifice. According to Santería doctrine, without periodic sacrifices, orishas could not survive. ${ }^{87}$ Animals sacrificed include chickens, goats, pigs, ducks, guinea pigs, and others. ${ }^{88}$

In April 1987, the Church of Lukumi Babalu Aye announced plans to open a Santería center in Hialeah, Florida. Community members and local government in Hialeah reacted swiftly and vociferously. Following the enactment of several emergency ordinances laying out the city's opposition to practices "inconsistent with public morals, peace or safety," and incorporating in full Florida's animal cruelty laws, the city council adopted four additional resolutions. The first was hortatory, noting the community's "great concern" about public animal sacrifices, that such practices violated state law, and announcing that anyone engaging in animal sacrifices would be prosecuted. ${ }^{89}$ The other three resolutions defined "sacrifice"; ${ }^{90}$ prohibited the ownership of any animal by anyone intending to use that animal for food ${ }^{91}$ declared the practice of sacrifice contrary to public health, safety, welfare and morals; outlawed it, ${ }^{92}$ and prohibited the slaughter of animals outside of areas zoned for that purpose..$^{93}$

The church filed an action against the city of Hialeah under 42 U.S.C. $\S 1983$, alleging violations of the Free Exercise Clause of the First Amendment ${ }^{94}$

85. 508 U.S. 520 (1993).

86. The Santería faith began when thousands of Yoruba people from west Africa were transported as slaves to Cuba. In Cuba, the religious practices of the Yoruba commingled with Roman Catholicism to form Santería, "The Way of the Saints." Santería has since spread to many parts of the Americas and has hundreds of thousands of adherents. See generally Migene GonZALEZ-WiPPLER, SANTERíA: THE RELIGION (2001); GEORGE BRANDON, SANTERÍA FROM AFriCA TO THE NEW WORLD: THE DEAD SEll MEMORIES (1993); JOHAN WEDEL, SANTERÍA HEAling (2004); SACRED PosSESSIONS: Vodou, SANTERÍA, OBEAH, AND THE CARIBbEAN (Margarite Fernández Olmos \& Lizabeth Paravisini-Gebert eds., 1997).

87. Lukumi, 508 U.S. at 525.

88. Id.

89. Prior to this resolution, Hialeah's city attorney obtained an opinion from the state attorney general that "ritual sacrifice of animals for purposes other than food consumption" did not comprise a "necessary killing" and was therefore prohibited under Florida's anti-cruelty statute. See FLA. STAT. $\S 828.12$ (1987) (holding criminally liable anyone who "unnecessarily or cruelly . . kills any animal").

90. Hialeah, Fla., Ordinance 52 (Sept. 8, 1987).

91. Id. (The statute contained an exemption for licensed establishments which slaughter animals "specifically for food purposes.")

92. Id.

93. Hialeah, Fla., Ordinance 72 (Sept. 22, 1987). The ordinance exempted the slaughter and processing of small numbers of hogs and cattle in accordance with exemptions provided by state law.

94. U.S. CONST. amend. I. 
and seeking declaratory, injunctive, and monetary relief..$^{95}$ The district court found for the city, holding that compelling governmental interests in preventing cruelty to animals and safeguarding public health justified the prohibition of animal sacrifice. The court further found that creating an exception for religious conduct would unduly impede the government's interest because the secret nature of Santería rituals would make narrower restrictions unenforceable. ${ }^{96}$ The Eleventh Circuit affirmed without substantive comment, except to note that the ordinances were consistent with the Constitution. ${ }^{97}$

The Supreme Court reversed in a plurality opinion authored by Justice Kennedy. ${ }^{98}$ The Court noted that under the Free Exercise Clause, a law that burdens religious practices need not undergo strict scrutiny if it is neutral and of general applicability. ${ }^{99}$ However, if the law is not neutral and is generally applicable, it must satisfy the strict scrutiny test- that is, it must be justified by a compelling governmental interest and narrowly tailored to advance that interest. ${ }^{100}$

The Court held that the Hialeah ordinances were not neutral because the city had "gerrymandered" the ordinances to exclude virtually all types of animal killings except those carried out by Santería adherents. ${ }^{101}$ Therefore, the ordinances were underinclusive as a means of accomplishing the city's interests in safeguarding public health and preventing animal cruelty. ${ }^{102}$ In addition, the city could accomplish its goals through other means than a blanket prohibition of ritual sacrifice. In this sense, the ordinances were overinclusive as well. ${ }^{103}$ Consequently, they could not survive strict scrutiny and had to be invalidated..$^{104}$

Although the opinion has many compelling threads, this article focuses on two sections. ${ }^{105}$ One of these states that " $[t]$ he legitimate governmental interests

95. In addition to the church itself, its leader, Ernesto Pichardo, was also a plaintiff. Named defendants in addition to the city included Hialeah's mayor and members of the city council. Church of the Lukumi Babalu Aye, Inc. v. City of Hialeah 508 U.S. 520, 528 (1993).

96. Id. at 530 .

97. Id. The Eleventh Circuit opinion now affirms without any comment. See 936 F.2d 586 (11th Cir. 1991).

98. Lukumi, 508 U.S. at 547. Although Justice Kennedy's opinion did not enjoy a majority in its entirety, the combination of the plurality and concurrences clearly hold the Hialeah ordinances unconstitutional. In a later settlement, Hialeah agreed to pay the legal fees incurred by Pichardo and the church totaling nearly half a million dollars and to pay one dollar to the church as a symbol of reconciliation. Neither Pichardo nor the church pursued further legal action against the elected officials named in the lawsuit. See DAVID M. O'Brien, ANimal SACRIfICE AND REligious FreEdom 160 (2004).

99. Lukumi, 508 U.S. at 546.

100. $I d$.

101. Id. at $535-36$.

102. $I d$.

103. $I d$. at 538 .

104. Id. at 540 .

105. Among the issues the opinion raises are the serious and disturbing undertones of ethnic and class-based discrimination that apparently inspired the actions of the Hialeah City Council. See id. at 535. That such issues fall outside the purview of this article is in no way meant to deprecate their importance or relevance to the decision. 
in protecting the public health and preventing cruelty to animals could be addressed by restrictions stopping far short of a flat prohibition of all Santería sacrificial practice. ${ }^{" 106}$ The Court reasoned that the city's interest in safeguarding public health, preventing cruelty to animals, and preventing cruel methods of killing could all be achieved through means that did not improperly target religious expression. The opinion concludes with the seemingly offhand observation that officeholders "must... ensure that the sole reasons for imposing the burdens of law and regulation are secular."107

\section{B. The Court's Contradictory Reasoning}

The Court's logic does not withstand close analysis. Accepting animal sacrifice as a protected mode of expression involves exempting a form of killing from normative scrutiny. The other forms of animal killing cited by the Court (hunting, fishing, slaughter for food, et cetera) are all at least nominally regulated. The Court's opinion embraces the idea that animal deaths are less important than the faith-based human value driving their killing. This position necessarily requires allegiance to the fundamentally religious precept that humans and animals are morally distinct and that humans occupy a privileged place in the ethical framework. ${ }^{108}$ It is here that the opinion becomes ensnarled in its own logic. Even as it insists that laws and regulations must be secular in origin, the Court stamps the religiously derived human-animal distinction with a constitutional imprimatur.

\section{Protecting Animal Sacrifice Is Itself a Religious Act}

Classifying animal sacrifice as protected religious expression involves several preliminary steps, none of which was articulated by the Court. The first unspoken premise is that humans and animals are incomparable beings with only humans enjoying moral agency. This distinction is based on belief unsubstantiated by fact and therefore fundamentally religious. ${ }^{109}$ Although the Free Exercise Clause indubitably protects religious expression from state suppression, it must be read in tandem with the Establishment Clause, which deprivileges any one religion over any other. ${ }^{10}$

Second, the law must conclude that sacrificial animals do not enjoy any inherent (as opposed to statutory) legal protections which might interfere with their demise. ${ }^{111}$ This involves weighing the interests of Santeríans in the

106. Id. at 538 .

107. Id. at 547 .

108. This reasoning is merely the judicial articulation of what Wolfe argues is an $u r$ principle of the western social structure-that "the full transcendence of the 'human' requires the sacrifice of the 'animal' and the animalistic." WOLFE, supra note 61, at 6.

109. See supra note 67 and accompanying text.

110. Engel v. Vitale, 370 U.S. 421, 430 (1962); Johnson v. Bd. of County Comm'rs of Bernalillo County, 528 F. Supp. 919, 921 (D.N.M. 1981), rev'd on other grounds, 781 F.2d 777 (10th Cir. 1985).

111. Although the Hialeah ordinances adopted in full Florida's anti-cruelty statute, the Court's analysis was based on the city's purported interest in preventing animal cruelty rather than the interests 
unfettered practice of their faith against the interests of the affected animals in not being ritually killed. Such a balancing test is fundamentally unworkable. As Gary Francione has persuasively argued, classifying animals as things means that their interests cannot possibly outweigh the interests of legal "persons." Things are property - a means to human ends-while humans are ends in themselves. ${ }^{113}$ Thus, weighing a person's interests against the tools used to accomplish those interests is incoherent. ${ }^{114}$ The interests of property cannot supplant property interests. ${ }^{115}$

Having implicitly taken these two steps in its reasoning, the Court could then couch the killing of animals as a legitimate form of religious expression. Since religious expression is constitutionally protected and animals are not, killing animals as a form of religious expression is protected as well. Conversely, attempts to deter the killing of animals when their deaths serve a human purpose face considerable judicial skepticism. Preventing animal sacrifice, in the Court's view, is simply not an important goal. The Court effectively says as much when it opines that Hialeah "has not demonstrated ... that, in the context of these ordinances, its governmental interests are compelling." 116

of the animals themselves. The animals' interests never entered the analysis. See Lukumi, 508 U.S. at 520 .

112. See FRANCIONE, supra note 53, at 117 ("The property status of animals renders meaningless any balancing... because what we really balance are the interests of property owners against the interests of their animal property.").

113. The idea of animal thinghood inevitably leads to a discussion of the status of domestic pets, which enjoy a degree of legal protection and judicial recognition that the billions of agricultural animals do not. Though a lengthy discussion of this issue lies beyond the purview of this article, it bears noting that the special status of domestic animals does not undermine their classification as things in the eyes of the law. Entire classes of things-including works of art, flags, and others-enjoy special legal status, but that does not alter their basic taxonomy. As Walter Benjamin observed, inanimate objects are capable of possessing "aura," a characteristic which heightens their exchange value and legal protections. Walter Benjamin, The Work of Art in the Age of Mechanical Reproduction, in ILLUMINATIONS 221 (Harry Zohns trans., Schocken Books 1969) (1968). See also JOSEPH L. SAX,

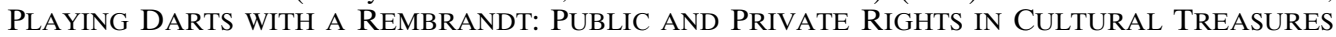
(2001) (chronicling society's discomfort with granting private property rights in culturally significant artifacts).

114. In comparing the experience of a subject of a life with that of things Tom Regan observes that the former have "inherent value [and] are not to be treated as if they were mere 'receptacles' of valuable experiences" of humans. REGAN, supra note 8, at 276-77.

115. See FrANCIONE, supra note 10, at 160 (noting that in the Lukumi case "the status of animals as property necessarily decided the religious issue"):

The property status of animals renders meaningless any balancing that is supposedly required under the humane treatment principle or animal welfare laws because what we really balance are the interests of property owners against the interests of their animal property. It is ... absurd to suggest that we can balance human interests ... against the interests of property, which exists only as a means to the ends of humans

Francione, supra note 53, at 117; see also Stephen M. Wise, Animal Rights, One Step at a Time, in ANimAl Rights: CURRENT DEBATES AND NEW Directions, supra note 7, at 19, 25 ("Humans are tyrants over things because they can be. Personhood is the legal bulwark that protects everybody... against human tyranny. Without it, one is helpless. Legally, persons count; things don't.").

116. Lukumi, 508 U.S. at 546. 


\section{Strict Scrutiny Was Misapplied}

The ordinances at issue in Lukumi targeted a specific practice (animal sacrifice-not animal killing) and were narrowly tailored to accomplish that goal. The city made plain that it did not approve of animal sacrifice, finding it immoral, cruel, and counter to community values. ${ }^{117}$ The statutes did not address other methods of animal slaughter or cruelty, and the Court considered that omission dispositive of a fatal underinclusiveness even as it also complained that the statutes were overbroad because they could have achieved their goal through means other than a blanket prohibition. This reasoning is problematic for several reasons.

a. The ordinances were narrowly tailored. According to the Court, the Hialeah laws failed because, among other reasons, "[m]any types of animal deaths or kills for nonreligious reasons are either not protected or approved by express provision." "118 The city's apparent indifference to other forms of animal killing, including fishing, hunting, and extermination, the Court noted, demonstrates that the ordinances impermissibly targeted religious expression by singling out animal sacrifice as the only type of prohibited slaughter. ${ }^{119}$ This reasoning impales itself on its own logic.

The ordinances aimed to accomplish a narrow goal-prohibiting ritual animal sacrifice - a type of killing the city (and state) deemed "unnecessary." The city did not take a position on or attempt to ban many other types of animal killing. The reasons for this seem clear; killing animals for food or for sport has little in common with ritual sacrifice other than that each involves animals dying. For example, it is possible to argue that killing animals for food is ethically defensible whereas killing them for ritual is not. One could likewise argue the converse. Similarly, one could argue that killing animals as part of a religious ritual is morally just while hunting animals for sport is not.

The ability to differentiate between and among these activities indicates that they are normatively distinct and therefore potentially subject to different restrictions. This would suggest not that the ordinances impose "a prohibition that society is prepared to impose upon [Santería worshippers] but not upon itself," ${ }^{121}$ but rather that the statutes sought to accomplish a narrow and targeted goal-prevention of ritual animal sacrifice..$^{122}$ Indeed, the Court acknowledges this when it observes, "The net result [of the ordinances] is that few if any killings of animals are prohibited other than Santería sacrifice, which is

117. This view was shared by Florida's attorney general, who, in response to a query by the city, opined that animal sacrifice was not a "necessary killing" and was therefore prohibited by the state's anti-cruelty statute. $I d$. at 527.

118. Id. at 543 .

119. Id. at 545 .

120. Id. at 537 .

121. Id. at 545 .

122. The Court quotes several Hialeah officials stating their clear opposition not to the killing of animals but rather to the use of animals in religious sacrifice. See id. at 541-42. 
proscribed because it occurs during a ritual or ceremony and its primary purpose is ... not food consumption." ${ }^{23}$ The Court seems troubled not because the statutes are insufficiently narrow but rather because they are too narrow.

b. The state interest was apparently not compelling. Given the narrowness of the Hialeah ordinances, it defies logic to argue that the statutes fail to accomplish their purpose because they fail to prevent behavior that they did not seek to regulate. One cannot imagine, for example, the Court striking down a statute prohibiting human sacrifice. It would not matter that other circumstances exist in which people are routinely killed (execution, euthanasia, military combat, et cetera). Nor would it matter that the laws as written proscribe killing in certain situations and places and not in others and that the anti-human sacrifice statute targets specifically religious behavior. The statute would survive because, despite its apparent underinclusiveness and focus on a specifically religious practice, it nevertheless satisfies a compelling state interest and is narrowly tailored to accomplish that goal.

It seems that the Court's objection to the Hialeah ordinances lay not with their inclusiveness (or lack thereof), but rather with a perceived lack of a compelling state interest. Prohibition of animal sacrifice involves suppressing religious expression in order to protect animal lives. That act would have potentially significant implications. Since the legal system is built around the notion that humans are ends and animals are means to those ends, enjoining conduct that expresses that distinction would seriously undermine the humananimal dichotomy upon which the system is built. ${ }^{124}$

\section{From Churches to Farms-Animals as Means to Ends}

The Lukumi Court used the circular reasoning underlying the humananimal divide to buttress that divide and grant it constitutional protection. ${ }^{125}$ It protected animal sacrifice as religious expression more deserving of protection than the animals killed in its practice. ${ }^{126}$ This reasoning implicitly dictates that human acts and beliefs deserve special protections under the law because humans are legally distinct from animals. The reason that humans are legally distinct from animals, however, is because the law codified that distinction. ${ }^{127}$ In

\section{Id. at 536 .}

124. Jacques Derrida argues that dividing humans from animals is an act of linguistic violence. It lumps the infinite multiplicity of nonhumans into one enormous umbrella category, "the animal," and subordinates it to "the human." He describes this "confusion of all non-human living creatures within the general and common category of the animal" as "a sin against rigorous thinking" and "a crime of the first order against ... animals." Derrida, supra note 79, at 416. Remedying this situation would, in Francione's view, require a revolutionary shift in the legal system wherein animals would no longer be classified as property. This would "entail dramatic economic and social consequences" and "[t]herein lies the intractable nature of the present controversy." FRANCIONE, supra note 10, at 261.

125. See supra note 84 and accompanying text.

126. See Lukumi, 508 U.S. at 544-47.

127. See Cetacean Cmty. v. Bush, 386 F.3d 1169 (9th Cir. 2004). 
other words, animals merit fewer legal protections because they have fewer legal protections.

Unsurprisingly, this same circularity underlies the lack of legal protections for animals on industrial farms. Animals raised for food lack legal protections because they are commodified property whose worth emanates from their market value. Yet they are commodified precisely because they lack legal protections. Exempting industrial farms from regulatory oversight requires accepting the commodity status of nonhuman animals and their concomitant lack of inherent value. Since that point of view is essentially faith-based, laws permitting such behavior privilege one religious perspective over another ${ }^{128}$ and should trigger a strict-scrutiny analysis under the Establishment Clause. ${ }^{129}$

In light of the increased societal acceptance of animal sentience and societal sensitivity to their suffering, as well as a growing uneasiness regarding their exclusion from the moral community, it is hard to see how statutes enabling industrial farms to gratuitously brutalize animals serve a compelling state interest. When one considers the environmental degradation wrought by industrial farms ${ }^{130}$ the disconnect between societal awareness and governmental neglect is dramatic.

If the predicates for factory farming lack any basis in science or ethics, the next question is what to do about it. Although simple legislative acts could incrementally ameliorate the situation (that is, granting birds the protections of the Humane Slaughter Act or doing away with the "Generally Accepted Practices" exemptions to animal cruelty laws), those steps would neither resolve the problem nor address the underlying issues. As Lukumi demonstrates, the exclusion of animals from the moral community and their consequent classification as things has been deeply woven into the legal and social system. That classification enables the deeply problematic practices of industrial farms. The root issue lies with the indefensibility of the human-animal distinction.

128. Not every religious tradition creates a hierarchy separating humans and other animals. See generally WALDAU, supra note 12. For example, Waldau contends that the Buddhist tradition recognizes the "continuity between humans and other animals." Id. at 138; see also Gregory Cajete, NATIVE SCIENCE: NATURAL LAWS OF INTERDEPENDENCE 150-51 (2000) (noting that many Native American spiritual traditions embrace a "fluid and inclusive perception of animal nature" which, in many cases, perceives nonhuman animals as mentors to humanity).

129. See Webster v. Reprod. Health Servs., 492 U.S. 490, 566-72 (1989) (Stevens, J., concurring in part and dissenting in part) (contending that Missouri abortion statute's preamble declaring that life begins at conception violates the Establishment Clause because it is "an unequivocal endorsement of a religious tenet ... that serves no identifiable secular purpose.").

130. See Warren Braunig, Reflexive Law Solutions for Factory Farm Pollution, 80 N.Y.U. L. REV.1505, 1505 (2005) ("Because the widespread existence of factory farms post-dates our nation's environmental laws, they remain largely exempt from emissions regulation."); Thomas R. Head, III, Local Regulation of Animal Feeding Operations: Concerns, Limits, and Options for Southeastern States, 6 ENVTL. LAW 503, 517 (2000) (explaining how nitrogen and phosphorous found in the large amounts of manure and animal waste generated by factory farms is ultimately discharged into water supplies); see also J.B. Ruhl, Farms, Their Environmental Harms and Environmental Law, 27 ECOLOGY L.Q. 263 (2000) (noting same). 
It cannot escape notice, however, that elevating nonhuman animals from the realm of "thinghood" will require reordering the social and legal systems. ${ }^{131}$ Critics of the animal-rights movement often complain that such a reordering is impossible to visualize and logistically unfeasible. ${ }^{132}$ How, then, to proceed? The first step in what must necessarily be a long and complex dialogue entails shifting focus from attempting to locate the boundaries of the human to exploring the frontier of the posthuman.

\section{$\mathrm{V}$ \\ IMAGINING A POSTHUMAN WORLD}

As has been often noted, part of the problem with the legal system is that the concept of "personhood" is unworkable and self-undermining. ${ }^{133}$ Along with the status of nonhuman animals, personhood fails to adequately address quandaries raised by embryos and fetuses, "brain-dead" people, corporations, nation-states, and others. The difficulty stems from the fact that "person" does not refer to a single concept but rather to a range of characteristics; it is a "cluster concept." 134 A cluster concept refers to the idea that person "does not stand for a single concept but rather for a cluster of ideas," including biological humanity, rational agency, and unity of consciousness (as in the case of corporations). ${ }^{135}$ The characteristics of personhood necessarily vary according to the type of entity under scrutiny. ${ }^{136}$

This heterogeneity can lead, and has led, to confusion over who and what is entitled to membership in the moral community. However, a properly implemented embrace of heterogeneity offers the promise of a reordered legal system wherein practical issues of need and ethical issues of compassion guide the statutory and adjudicative processes. The reordering must start with two fundamental assumptions: 1) the boundaries between human and nonhuman have always been and are becoming increasingly problematic, and 2) the legal concept of "personhood" is inadequate to the task of allocating legal and moral entitlements.

131. See, e.g., Steven M. Wise, Animal Thing to Animal Person: Thoughts on Time, Place, and Theories, 5 ANIMAL L. 61, 61 (1999) ("On one side, every human is a person with legal rights; on the other, every non-human is a thing with no legal rights. Every animal rights lawyer knows that this barrier must be breached."); see also Steven M. Wise, Dismantling the Barriers to Legal Rights for Nonhuman Animals, 7 ANIMAL L. 9, 12 (2001) (explaining why a non-human animal's "legal thinghood" renders it invisible to a civil judge's constitutional eyes).

132. See Cass R. Sunstein, The Rights of Animals, 70 U. CHI. L. REV. 387, 387-89 (2003).

133. Id.

134. See, e.g., Degrazia, supra note 8, at 42; Jens David Ohlin, Note, Is the Concept of Personhood Necessary for Human Rights? 105 COLUM L. REV. 209, 228-30 (2005) (respectively offering the cluster concept as more viable replacement for personhood).

135. Ohlin, supra note 134, at 230; David N. Cassuto, Crime, War and Romanticism: Arthur Andersen and the Nature of Entity Guilt, 13 VA. J. SoC. POL'Y \& L. 179, 217 (Winter 2006) (noting that the "concept of a collective entity having its own discrete identity enjoys wide acceptance in everyday speech and thought, both legal and colloquial").

136. See Ohlin supra note 134, at 213. 


\section{A. Personhood Serves No Legal Function}

Personhood refers to those beings possessing the requisite characteristics for access to the legal system. ${ }^{137}$ As such, the word is overtaxed to the point of nonreferentiality. ${ }^{138}$ This linguistic stress will only worsen as technological advances further muddy the distinctions between humans, nonhumans, and machines. One could imagine a lively debate, for example, regarding the personhood of a cloned Homo sapiens with a pig's heart, a mechanical arm, and genetically altered DNA. That debate, while epistemologically interesting, ought to have little or no legal relevance. One need not be a person in order to have rights; rather, one needs rights in order to be a person. ${ }^{139}$

When determining whether a being possesses rights, the question should not be whether the aspirant is a "person" but rather whether it possesses the qualities that personhood references. ${ }^{140}$ Personhood becomes irrelevant as the investigation shifts to a determination of the salient qualities for the conferral of rights. ${ }^{141}$ This reordering and reevaluation of the language of law forms the first step toward creating a posthuman legal landscape.

Past attempts to differentiate humans from animals have taken many forms. Some, like Descartes, maintained that the difference lay with the capacity for language. ${ }^{142}$ Others based it on intellectual ability, self-consciousness, or basic

137. Interestingly, the etymology of "person" traces back to the Latin persona, which means mask, especially of the type worn by actors or those playing social roles. Only later did the concept evolve into the Roman idea of a bearer of legal rights. Later, Locke defined it as a possessor of a certain type of consciousness. See Degrazia, supra note 8, at 40. Modern law seems to merge the Lockean and Roman definitions.

138. Jacques Derrida argues that this same phenomenon has long plagued the term "animal."

Confined within this catch-all concept, within this vast encampment of the animal ... are all the living things that man does not recognize as his fellows, his neighbors or his brothers. And that is so in spite of the infinite space that separates the lizard from the dog, the protozoon from the dolphin, the shark from the lamb, the parrot from the chimpanzee.

Derrida, supra note 79, at 402.

139. See Ohlin, supra note 134, at 237 ("We do not ascribe human rights because an entity is a person-it is a person because we ascribe human rights to it.").

140. See WOLFE, supra note 61 , at 42 , noting that

when our generally agreed-on markers for ethical consideration are observed in species other than Homo sapiens, we are obliged to take them into account equally and to respect them accordingly. This amounts to nothing more than taking the humanist conceptualization of the problem at its word and being rigorous about it—and then showing how humanism must, if rigorously pursued, generate its own deconstruction once these "defining" characteristics are found beyond the species barrier.

141. Neil Evernden articulates this concept almost as a modified Gaia principle- that we are all part of the same Nature and that Nature, as the aggregation of all of us, is entitled to personhood:

[W] hen we disabuse ourselves of the notion that we are merely skin-encapsulated egos, and realize that we actually have a "field of care" in which we dwell, which makes us literal participants in the existence of all beings, then we will realize that to harm nature is to harm ourselves. Nature is, then, an extended self, and is entitled to the same concern as any other person.

NeIL EVERnden, THE Social CREATION OF NATURE 100-01 (1992).

142. See Animal Rights And Human Obligations 62 (Tom Regan \& Peter Singer eds., 1976) (citing RenÉ Descartes, Discourse on Method). Several centuries later, Ludwig Wittgenstein offered a probing interrogation of the nature of language and the human condition when he observed, 
biology. ${ }^{143}$ None of these rationales withstands close analysis. Nonhuman language capability has been conclusively demonstrated in innumerable cases,${ }^{144}$ while differentiating based on intellect founders on the existence of cognitively impaired people who are nonetheless classified as human. Basic biology is also a thin reed on which to hang one's humanity. No quintessentially "human" characteristic has emerged to definitively set humans apart from other animals. ${ }^{145}$ This should not surprise, given that the human genome differs only minimally from that of a roundworm. ${ }^{146}$

Furthermore, scientific advances in recent years have tied humans and nonhumans even more closely. As Judge Amestoy observed in an essay on the emerging posthuman legal landscape, "The posthuman world will ... contain creatures that are part human and part animal. It will contain machines that may be sentient and likely will have greater cognitive capacities than animals or humans." ${ }^{147} \mathrm{He}$ notes also that the emergence of chimeras-"genetically engineered creature[s] comprised of human and animal genes"-will pose a thorny standing issue for future litigations. ${ }^{148}$

"If a lion could talk, we could not understand him." PhiLOSOPHICAL InVESTIGATIONS 223 (G. E. M. Anscombe trans., MacMillan 1965) (1953). Wittgenstein's Lion, as this image has come to be known, forms the basis of numerous ruminations on the nature of humanity. While at first reading the passage seems to suggest that the lion is unable to speak, it also suggests that the lion is simply not speaking to us. The lion's reticence, argues poet and animal trainer, Vicki Hearne, "is not the reticence of absence, absence of consciousness ... or knowledge, but rather of tremendous presence" of "all consciousness that is beyond ours." WOLFE, supra note 61, at 45.

143. See, e.g., P.F. STRAWSON, INDIVIDUALS, AN ESSAY IN DESCRIPTIVE METAPHYSICS 104 (1959) (arguing that the concept of personhood "is to be understood as the concept of a type of entity such that both predicates ascribing states of consciousness and predicates ascribing corporeal characteristics ... are equally applicable to an individual entity of that type."); see also Ohlin, supra note 134, at 213-14 n.25 (quoting same).

144. See STEINER, supra note 8, at 18-21.

145. See Tom Regan, Empty CAgEs: FACing the Challenge of ANimal Rights 44-52 (2004) (rejecting conventional criteria for reserving rights for humans and arguing for their allocation on the basis of similarity among creatures rather than difference).

146. See About the Human Genome Project, http://www.4uth.gov.ua/usa/english/tech/biotech/ about.htm (last visited May 8, 2006) (explaining that roundworms and other organisms were used as basis of research for the Human Genome Project because roundworms have similar genes). As W.J.T. Mitchell notes, "A person, after all, is from one point of view, just another thing." WOLFE, supra note 61 , at xii. If this is so, then like any arbitrarily conferred status, it has meaning only through its acceptance by others. Accepting then that personhood is inherently subjective implicitly revokes its status as an ontological category. This observation is another way of stating what Arendt and others have argued, which is that personhood is conferred or revoked at the pleasure of the sovereign. See ARENDT, supra note 49, at 279-80. For Arendt, rendering someone stateless is the equivalent of stripping them of personhood; she notes that the Nazis took great care to strip Jews of their citizenship before deporting them so that they could suffer the full impact of being rendered stateless.

147. Jeffrey L. Amestoy, Uncommon Humanity: Reflecting on Judging in a Posthuman Era, 78 N.Y.U. L. REV. 1581, 1592 (2003).

148. Id. at 1585. See also Mitchell's introduction to Wolfe's ANIMAL RITES, wherein he notes "The question of the animal is just one component in a rethinking of a whole set of nonhuman entities that seem to take on organic, lifelike, or 'autopoietic' characteristics-intelligent machines, of course, but also systems and swarms, viruses and coevolutionary organisms, corpses, corpora, and corporations, images and works of art." WOLFE, supra note 61, at xiii. He terms the new world of hybrid creatures "humanimals." Id. 
Courts and legislatures have struggled to adapt to this shifting epistemological landscape with little success. No one definition of "person" comfortably encompasses the range of legal entities with claims to its mantle. Steven Wise argues that courts elide the problem by cluttering the taxonomic landscape with legal fictions devised to sustain an arbitrary and exclusionary status quo. ${ }^{149}$

Broadening the ambit of personhood will not solve the predicament. Regardless of how wide its scope, the term will always define itself through contrast with an excluded other. It requires that those possessing the requisite characteristics evaluate whether other beings do as well. In this sense, even as a broader conception of personhood validates other beings as worthy of moral considerations, it does so by evaluating whether their essence sufficiently resembles our own. ${ }^{150}$

This technique for awarding ethical consideration suffers from the same vicious circularity as Freud's explanation of human evolution. Even as it seeks to remove the human orientation within the law, this scheme nevertheless presupposes an $U r$ person against which aspirants to the moral community must evaluate themselves. That $U r$ person must have existed as a right-holder prior to the determination of the essential characteristics for rights. Given that the legal system formed within human society, the $U r$ person must necessarily be human. In this sense, all aspirants to legal personhood must demonstrate that they share some "human" traits. Consequently, any attempt to frame a set of criteria for personhood begins with an inherently speciesist bias.

One way to address this problem is by doing away with personhood as a dispositive legal category. As an umbrella term encompassing a cluster of traits, personhood obfuscates rather than clarifies the issue of moral and legal responsibility. Any discussion of rights and membership in the legal community would be better served by focusing on the components of the term rather than the term itself..$^{151}$

149. WISE, supra note 8, at 31-32.

150. See Paul W. Taylor, The Ethics of Respect for Nature, 3 ENVTL. ETHICS 197 (1981). In a section titled "The Denial of Human Superiority," Taylor argues that "human characteristics... are all valuable to humans," and that "it is from the human standpoint that they are judged to be desirable and good." Id. at 211-18; see also Taimie L. Bryant, Similarity or Difference as a Basis for Justice: Must Animals Be Like Humans to Be Legally Protected from Humans?, 70 LAW \& CONTEMP. PROBS. 207 (Winter 2007).

151. See, e.g., Mary Ford, The Personhood Paradox and 'The Right to Die,' 13 MeD. L. REV. 80 (2005) (explaining that when legal personhood is defined by a collection of traits that equate to "superior moral status," we must then decide which traits are relevant and which are not); D. Scott Bennett, Chimera and the Continuum of Humanity: Erasing the Line of Constitutional Personhood, 55 EMORY L.J. 347, 369-70 (2006) (explaining that in the medical community, when a human has lost those traits that make them a person, such as "higher level brain function," we consider them to have died even though their respiratory and cardiac system is still functioning). 
Different traits demand different entitlements. Clustering them all beneath the term "personhood" invites imprecision. ${ }^{152}$ By contrast, separating the term into components allows the legal system to treat difference differently while still enabling access to the moral community. Thus, replacing personhood with a cluster concept of rights offers a point of embarkation to the posthuman world.

\section{B. Different Characteristics Create Different Entitlements}

Each of the currently acknowledged criteria for rights corresponds to a different sort of being with different societal and legal requirements. Those who claim rights based on biology (newborn infants, brain-dead adults, for example) have different requirements than those whose claim rests on rational agency (adult homo sapiens), who in turn differ from group entities (corporations, nation-states). Then we face the emerging category of those who do not fit neatly into any of the presently acknowledged categories but who nonetheless may be entitled to some form of societal protections (nonhuman animals, chimeras, artificial intelligences, et cetera).

That there exists a multiplicity of beings with varying demands on the legal system does not undermine the premise that traditionally disenfranchised beings could and should enjoy expanded legal entitlements. As many commentators have noted, granting rights to nonhuman animals does not mean granting them the same rights that humans enjoy. ${ }^{153}$ The latter idea is both absurd and counterproductive. As Peter Singer observed, a cow could happily live her entire life on a pasture in New Jersey. The same could not necessarily be said of a human. ${ }^{154}$ Therefore, the entitlements and protections to which cows and humans should respectively be entitled vary as well. ${ }^{155}$

A posthuman legal landscape acknowledges these differences. It allocates protections based on the requirements of the various beings that form the moral community. ${ }^{156}$ This could mean, for example, that since farm animals are sentient and have the capacity to suffer, they should not be subjected to the grotesque and inhumane conditions of the factory farm. ${ }^{157}$ However, it may not mean that an agricultural system wherein farm animals live comfortably

152. As Ohlin, paraphrasing philosopher W.V. Quine, observes, "[W]ords have only as much precision as our current needs have required and is foolish to search for greater precision where none exists." Ohlin, supra note 134, at 230.

153. See, e.g., Anderson, supra note 7, at 281-93, especially 290 (arguing that "there is no single criterion of moral considerability," and "what rights should be extended to a creature depend not only on its individual intrinsic capacities, but on its species nature, its natural and social relations to the moral agents to whom rights claims are addressed, and the social and historical background conditions applicable to the moral agents themselves").

154. See Singer, Introduction to In Defense of AnimAls: The SeCOND WAVE, supra note 5, at 5.

155. See Id. at 4-5; WOLFE, supra note 61, at 34.

156. Borrowing Aldo Leopold's phrase from the "Land Ethic," this would "change[] the role of Homo sapiens from conqueror of the land community to plain member and citizen of it." ALDO LEOPOLD, A SAND COUNTY ALMANAC 204 (1949).

157. See Sunstein, supra note 53, at 1335. 
protected from disease and predators is necessarily unacceptable. This issue can and should form the basis for reasoned debate. ${ }^{158}$

Similarly, domestic animals have a right to food, comfort, and friendship from their human companions. ${ }^{159}$ They also have a right to bodily integrity. However, given the demands that these expectations place on humans, and the structure of society, it does not seem per se unreasonable to require that domestic animals be neutered or spayed..$^{160}$

Both of the above scenarios involve a rights framework drastically different from the one that humans enjoy. Therein lies the flexibility of the posthuman, cluster approach to rights. Legal entitlements vary according to the nature and needs of the user.

Clear also from these examples is that the allocation of rights among nonhumans can seem arbitrary and unjust. Why, for example, should a pig raised in a domestic living environment have legal entitlements that another pig raised on a farm does not? There is no easy answer to this query except to note that a positivist legal framework is inherently arbitrary. ${ }^{161}$ Happenstance rather than fairness often determines the nature of the rights allotted. This is as true for humans-whose comfort and access to legal protections is often ethnically and geographically dependent-as for nonhumans. ${ }^{162}$

The above-described approach to rights in a posthuman world remains vulnerable to the criticism that it allocates entitlements based on the aspirant's possession of characteristics that humans classify as worthy. In this sense, it is prone to speciesism because it fails to validate "otherness," instead rewarding human analogs when and if they appear in other beings. ${ }^{163}$ This criticism should provide the seeds for future discussion.

158. The approach I am suggesting in many ways resembles the "capabilities approach" offered by Martha Nussbaum. See Nussbaum, supra note 53, at 310-17. However, Nussbaum predicates her vision of species-specific rights on what she calls a "respectful paternalism," id. at 314-15, which assumes that humans should and do govern the moral community. My view is that presuming a privileged role for humans, even if a duty of compassion attaches to it, will lead inexorably to a discussion of the limits of nonhuman self-governance rather than an exploration of its frontiers.

159. See, e.g., McCall v. State, 540 S.W.2d 717 (Tx. Crim. App. 1976).

160. Though the issue of the use of nonhuman animals in biomedical research has not been addressed in this essay, it is clearly implicated in this rights framework I am proposing. The longer discussion of the issue is a topic for another day, but I would here observe that the same logic applies to laboratory research as applies to factory farms. If we acknowledge that sentient nonhumans have a right to a life free from human-imposed torment, the argument for vivisection becomes increasingly problematic.

161. Frances J. Mootz, III, Is the Rule of Law Possible in a Postmodern World, 68 WASH. L. REV. 249, 274 (1993) ("The cornerstone of positivism is that the commands of a legitimate sovereign must be recognized as law."); REGAN, supra note 8, at 267 ("Whether individuals have legal rights depends on the laws and other legal background... of the society in which they live.... This should not be surprising. The legal rights individuals have arise as the result of the creative activity of human beings.").

162. See TONy Judt, Postwar: A History OF Europe SinCE 1945, 803-08 (2005) (describing the numbers of Jews deported or killed in various European nations).

163. See, e.g., WOLFE, supra note 61, at 16 (describing how even attempts to reformulate the human-nonhuman ethical relationship serve only to "reinforce the very humanism it seems to subvert"); see also Bryant, supra note 150. 
Critics of animal rights often complain that advocates fail to articulate a workable alternative to the human-centered legal discourse and dismiss rights for nonhumans on that basis. ${ }^{164}$ Although it is arguably true that the legal vocabulary for expressing a nonexploitive relationship with nonhumans remains in the formative stages ${ }^{165}$ this seems almost irrelevant for present purposes. A status quo wherein animals are casually and routinely brutalized is ethically insupportable. If the current linguistic tools seem inadequate to the task of social change, then reshaping those tools seems all the more urgent.

\section{VI \\ CONCLUSION}

The status quo, based as it is on a specious and unsustainable divide between humans and other beings, is legally suspect and ethically bankrupt. It has allowed a fundamentally religious idea to govern access to the legal system and has enabled a brutal, amoral commercial enterprise to operate with little regulatory oversight.

To argue for the current system's preservation because the alternatives are imperfect is to dismiss a moral imperative in the name of short-term expedience. Normative reconfiguration never happens easily. There is, however, no other option. The posthuman era has dawned. The only question remaining is what we will do about it.

164. See, e.g., Richard Posner, Animal Rights: Legal, Philosophical, and Pragmatic Perspectives, in Animal Rights: CURRENT DeBATES AND NEW Directions, supra note 7, at 51, 56 (critiquing Steven Wise's incremental approach to granting rights to nonhumans because it offers insufficient guidance to judges).

165. See id. at 71 ("The more we think about the [implications of abolishing animal servitude], the less apt the vocabulary of 'rights' seems."). 